\title{
Notes on Courtship and Breeding Behavior of the Andaman Day Gecko, Phelsuma andamanensis Blyth 1861 (Reptilia: Gelkonidae), in the Andaman Islands
}

\author{
S.R. Chandramouli
}

Department of Ecology and Environmental Sciences, School of Life Sciences, Pondicherry University, Puducherry-605014, India (findthesnakeman@gmail.com)

Photographs by the author.

$\mathrm{D}$ ay geckos in the genus Phelsuma Gray 1825 are represented by 52 species distributed mostly in the AfroMalagasy region (Uetz et al. 2019). The Andaman Day Gecko ( $P$. andamanensis Blyth 1861) is the sole representative from the oriental Andaman Archipelago (Blyth 1861; Das 1999). Ratnam (1992) conducted the only targeted study on $P$. andamanensis, addressing its distribution and behavior in the Andaman Archipelago, including descriptions of breeding behavior that included displays such as "genital nudge" and "hind-leg raising walk" in males and females, respectively. Herein, I report an observation of courtship behavior in $P$. andamanensis on 31 January 2016 on Havelock Island $\left(11.98^{\circ} \mathrm{N}, 92.99^{\circ} \mathrm{E}\right.$; elevation $108 \mathrm{~m}$ asl) in the Ritchie's Archipelago of the Andamans.

An adult female Andaman Day Gecko, sex identified on the basis of coloration (uniform green and patternless) and the absence of a hemipenal bulge, was perched on a banana plant (Musa paradisiaca) about $1 \mathrm{~m}$ above the ground at 1054 h. An adult male, sex identified based on coloration (reddish orange spots and streaks on a bright green dorsum and a bluish-green head and tail) and the presence of an evident hemipenal bulge), was perched slightly below the female on the same plant. The male approached the female slowly from behind and touched her tail before nudging her cloacal region with his snout (Fig. 1). When the female apparently indicated that she was receptive to the male's approach, he mounted her. Copulation lasted for a few minutes until the female released herself from the male's grip.

On 26 February 2016, I observed a juvenile Phelsuma andamanensis (19 mm SVL, $35 \mathrm{~mm}$ total length; Fig. 2) in the Interview Island Wildlife Sanctuary. In March 2016, I found another juvenile that had been captured by a juvenile Andaman Bronzeback (Dendrelaphis andamanensis) on Long
Island. Das (2002) indicated that $P$. andamanensis breeds throughout the year and Whitaker and Whitaker (1979) suggested that the monsoon (May) could be the main hatching

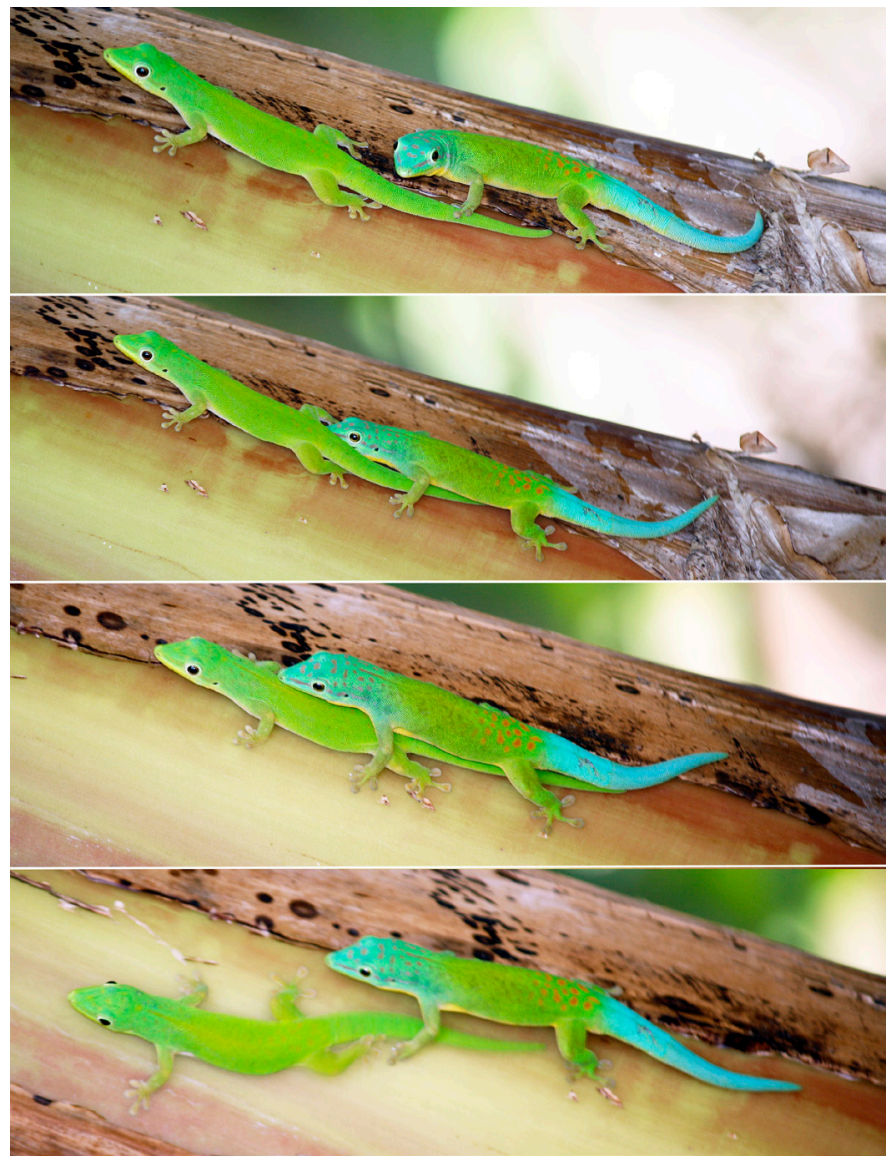

Fig. 1. Courtship and copulation in Andaman Day Geckos (Phelsuma andamanensis) on a banana plant on Havelock Island in the Andaman Archipelago. The male approaches the female, touches her tail (A), nudges her cloacal region (B), and mounts her (C), before the female withdraws (D). 


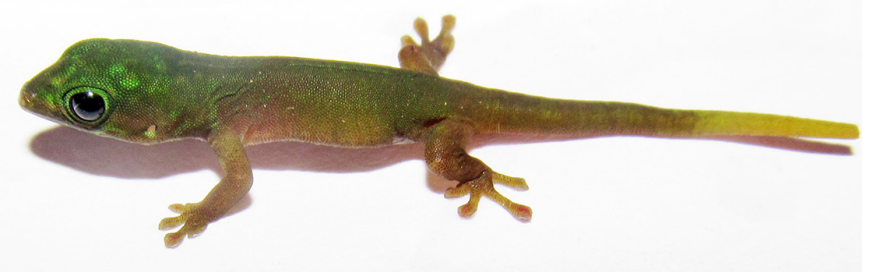

Fig. 2. A juvenile Andaman Day Gecko (Phelsuma andamanensis) in the Interview Island Wildlife Sanctuary of the Andaman Archipelago.

season. These observations of what appeared to be recently hatched juveniles prior to the monsoon tentatively support Das's (2002) contention of year-round breeding.

\section{Literature Cited}

Blyth, E. 1861. Proceedings of the Society. Report of the Curator. Journal of the Asiatic Society of Bengal 29: 87-115.

Das, I. 1999. Biogeography of the amphibians and reptiles of the Andaman and Nicobar Islands, India, pp. 43-77. In: H. Ota (ed.), Tropical Island Herpetofauna: Origin, Current Diversity, and Conservation: Proceedings of the International Symposium, "Diversity of Reptiles, Amphibians, and Other Terrestrial Animals on Tropical IslandsOrigin, Current Status, and Conservation," held at the University of Ryukyus, Okinawa, Japan, from 6 to 7 June 1998. Elsevier Science BV, Amsterdam, The Netherlands.

Das, I. 2002. A Photographic Guide to Snakes and Other Reptiles of India. New Holland Publishers, London, UK.

Ratnam, J. 1992. Distribution and behavioural ecology of the Andaman Day Gecko (Phelsuma andamanensis). Unpublished M.S. Dissertation, Pondicherry University, Puducherry, India.

Uetz, P., P. Freed, and J. Hošek (eds.). 2019. The Reptile Database. <www.reptiledatabase.org>.

Whitaker, R. and Z. Whitaker. 1979. Notes on Phelsuma andamanense, the Andaman day gecko or green gecko. Journal of the Bombay Natural History Society 75: 497-499. 
